\title{
POLLINATION AND NECTAR LARCENY BY BIRDS AND BEES IN NOVEL FORESTS OF THE HAWAIIAN ISLANDS
}

\author{
Pryce W. Millikin', Samuel B. Case' ${ }^{2}$ and Corey E. Tarwater ${ }^{2}$ \\ 'Department of Botany, University of Wyoming, Laramie, WY 82071, USA \\ ${ }^{2}$ Department of Zoology and Physiology and Program in Ecology, University of Wyoming, Laramie, WY 82071, USA
}

Journal of Pollination Ecology, 29(15), 2021, pp 189-203

DOI: $10.26786 / 1920-$

$7603(2021) 640$

Received 23 February 2021, accepted 30 June 2021

*Corresponding author:

pryce.millikin@gmail.com

\begin{abstract}
The extinction of native species and introduction of non-native species may lead to the disruption of biotic interactions. Pollination is a critical ecosystem process that often requires mutualisms between animals and plants. Non-native animals may interact with native flowering plants, with the potential to pollinate or steal nectar (larceny) from flowers without pollination. In the Hawaiian Islands, many native plants have lost their original pollinators. Birds and insects are known to visit native plant flowers, but it is unclear whether they pollinate or steal nectar, whether native and non-native species differ in their interactions with flowers, and what influences visitation to flowers. On O'ahu, we deployed camera traps and conducted in-person observations on four at-risk species of Hawaiian lobelioids (Campanulaceae). We observed birds, mammals, and insects visiting flowers, with a native bird and native bee visiting most frequently. Regardless of native versus non-native status, bees made contact with reproductive structures during most visits ( $90.5 \%$ of visits), while birds stole nectar during most visits (99.3\% of visits). Bee and bird visitation increased with the number of flowers on focal plants. Bird visitation also increased with canopy cover and the number of nearby conspecific flowers and decreased with the number of nearby heterospecific flowers. Our results indicate that bees may pollinate plants that were historically bird-pollinated, while native and non-native birds have neutral or negative impacts on these plants. Broadly, we contribute to an understanding of how native plant pollination can be altered in changing ecosystems.
\end{abstract}

Keywords-Pollination, nectar larceny, nectar robbing, novel ecosystems, extinction driven change, invasion impacts

\section{INTRODUCTION}

Rates of species extinction and invasion are accelerating worldwide, leading to a new suite of species co-existing and forming novel ecosystems (Hobbs et al. 2009). If and how species interact, and the subsequent impacts on biodiversity and ecosystem function are often uncertain in novel ecosystems (Morse et al. 2016). For example, mutualistic interactions, such as seed dispersal or pollination, can be lost, gained, or altered in response to shifts in the community, with differential impacts on animal and plant populations (Vaughton 1996; Ollerton et al. 2009; Anderson et al. 2011). Mutualisms are known to be particularly vulnerable to environmental changes and this may be even more true on island ecosystems, where populations tend to be small and evolution has occurred in isolation (Traveset \& Richardson 2006; Tylianakis et al. 2008; Mitchell et al. 2009; Kiers et al. 2010). Therefore, examining these interactions in novel island ecosystems is critical for predicting species persistence and conserving biodiversity in response to global change.

Pollination is often needed for seed production and genetic connectivity between plant populations, affecting population persistence and community structure (Castilla et al. 2017). Pollination typically requires mutualistic interactions between animals and flowering plants (Bond 1994). Pollination mutualisms can be highly specialized, with plant and animal partners 
exhibiting matched functional traits (e.g., matching of bird bill and floral tube shapes) to improve gene transfer between plants and to improve nectar or pollen acquisition for animals (Krauss et al. 2017). However, pollination mutualisms can be cheated through floral larceny. Here we use the term nectar larceny; this occurs when animals obtain nectar rewards while bypassing structures for pollen transfer, with (e.g., nectar robbers) or without (e.g., nectar thieves or base workers) damaging floral tissues (Inouye 1980; Irwin et al. 2010). Nectar larceny may reduce visitation of legitimate pollinators by decreasing potential rewards and shortening floral longevity (Inouye 1980; Irwin et al. 2001). The loss of pollinators, increase in nectar larceny, or shifts in the frequency of floral interactions may increase risk of pollination limitation for plant populations (Vaughton 1996; Pratt et al. 2010; Abe et al. 2011; Anderson et al. 2011). Alternatively, the introduction of pollinators may serve as valuable substitutes for lost pollinator species (Lord 1991; Ollerton et al. 2009; Pattemore \& Wilcove 2012).

The frequency of interactions between animals and flowering plants may depend on traits of the focal plant and the surrounding floral neighbourhood, including the number of flowers on the focal plant, the number of flowers in the neighbourhood, and canopy cover (Ghazoul 2005; Nottebrock et al. 2017; Santos et al. 2018). For instance, a greater number of flowers on the focal plant may increase animal visitation by increasing detection of the plant and signalling higher resource availability (Eckhart 1991; Harder \& Barrett 1995; Conner \& Rush 1996). An increased number of flowers in the surrounding neighbourhood may either reduce focal flower visitation, owing to competition for visitors, or increase visitation, by attracting animals to an area (Rathcke 1983; Ghazoul 2005). These outcomes may vary with pollinator type and whether the neighbourhood flowers are from conspecific or heterospecific plants (Nottebrock et al. 2017). For example, for visitors that specialize on particular plants, the number of conspecific flowers, but not the number of heterospecific flowers in the neighbourhood, is predicted to influence visitation (Lázaro et al., 2009). In contrast, for generalist visitors, the number of flowers in the neighbourhood, whether conspecific or heterospecific, may impact visitation (Lázaro et al. 2009). Furthermore, increased canopy cover can either increase visitation to plants, by providing perching sites, or can decrease visitation, by concealing flowering plants (Kolb \& Ehrlén 2010; Hopson et al. 2020).

In a novel forest ecosystem of $\mathrm{O}^{\prime} \mathrm{ahu}$, Hawai'i, where over $65 \%$ of plant cover (Vizentin-Bugoni et al. 2019), $86.7 \%$ of forest bird species (VizentinBugoni et al. 2019), and 30\% of bee species are nonnative (Snelling 2003), we examined visitation to flowers of four at-risk Hawaiian lobelioids (Campanulaceae) (Tab. 1). We documented the

Table 1. Description and conservation status of lobelioid species examined.

\begin{tabular}{|c|c|c|c|c|}
\hline Species & Delissea waianaeensis & $\begin{array}{l}\text { Cyanea grimesiana } \\
\text { obatae }\end{array}$ & Cyanea longiflora & $\begin{array}{l}\text { Clermontia } \\
\text { persicifolia }\end{array}$ \\
\hline Growth form & Woody shrub $(1-2.5 \mathrm{~m})^{1}$ & Woody shrub $(1-3.2 \mathrm{~m})^{2}$ & Woody shrub $(1-3 m)^{3}$ & Shrub/tree $(2-6 m)^{4}$ \\
\hline Corolla colour & White, greenish-white 5 & $\begin{array}{l}\text { Greenish-white, } \\
\text { yellowish-white, } \\
\text { purplish-white, striped } \\
\text { with magenta5 }\end{array}$ & Dark magenta5 & $\begin{array}{l}\text { White, greenish- } \\
\text { white }^{5}\end{array}$ \\
\hline Corolla length (mm) & $44-60^{5}$ & $55-80^{5}$ & $60-90^{5}$ & $48-60^{5}$ \\
\hline Conservation status & $\begin{array}{l}\text { Critically endangered } \\
(\text { ICUN })^{1}\end{array}$ & $\begin{array}{l}\text { Critically endangered } \\
(\text { ICUN })^{2}\end{array}$ & $\begin{array}{l}\text { Critically endangered } \\
(\text { ICUN) })^{3}\end{array}$ & $\begin{array}{l}\text { Near threatened } \\
(\text { ICUN })^{4}\end{array}$ \\
\hline Distribution (sq km) & $32 \mathrm{~km}^{1}$ & $12 \mathrm{~km}^{2}$ & $1 \mathrm{~km}^{3}$ & Unknown \\
\hline $\begin{array}{l}\text { Estimated population } \\
\text { number }\end{array}$ & $169^{1}$ & $16^{2}$ & $79^{3}$ & Unknown \\
\hline
\end{tabular}

'(Keir, M., Portner, T., Caraway, V.L. \& Kwon, J. 2015); 2(Keir 2015); 3(Keir, M., Kwon, J., Caraway, V.L. \& Weisenberger, L 2015); 4 (World Conservation Monitoring Centre 1998); 5 (Wagner et al. 1999) 
identity of species visiting lobelioid flowers and whether native and non-native animal species made contact with or bypassed reproductive structures (stigma or pollen brush at the tip of the staminal column) while feeding on pollen or nectar. We also examined if and how the characteristics of the focal plant and the floral neighbourhood influenced visitation. Since human arrival in the Hawaiian Islands ( $\sim 800$ years ago) (Wilmshurst et al. 2011), forest ecosystems have undergone major changes owing to high rates of species extinction and introduction (Boyer 2008; Elphick et al. 2010). Studies of pollination in Hawai'i have observed both native and non-native birds and insects playing a role in pollination of native plants, as well as observations of nectar larceny by native and non-native birds (Cox 1983, Junker et al. 2010, 2011, Pratt et al. 2010, Koch \& Sahli 2013, Aslan et al. 2014, 2016, Hanna et al. 2014, Freed et al. 2016, Shay et al. 2016). However, rates of pollination versus nectar larceny between birds and insects visiting native Hawaiian flora, in addition to factors affecting visitation, remain uncertain. Nectar analyses and morphological traits (e.g. floral tube shape) suggest that most genera of Hawaiian lobelioids (all except Brighamia) (Walsh et al. 2019) were originally pollinated by birds with long bills, including honeycreepers (Drepanidae) and 'ō'ōs (Mohoidae) (Pender et al. 2014, Walsh et al. 2019). Owing to the extinction or decline in populations of historic pollinators (Elphick et al. 2010; Magnacca \& King 2013) in modern forests, present lobelioid pollinators may potentially include remaining native species of honeycreeper (original pollinating species are not likely present on $\mathrm{O}^{\prime} \mathrm{ahu}$ ) and yellow-faced bees (Hylaeus sp.), as well as nonnative birds and western honey bees (Apis mellifera) (Lammers et al. 1988, Kevin M. Roddy 1997, Koch \& Sahli 2013). There is limited evidence from $\mathrm{O}^{\prime} \mathrm{ahu}$ that the non-native warbling whiteeye (Zosterops japonicus) and the yellow-faced bee visit lobelioid flowers, that warbling white-eyes may rob nectar, and the flowers of some lobelioid species are never visited by animals (Gardener \& Daehler 2006; Cory et al. 2015). Ecological communities are rapidly changing worldwide (Hobbs et al. 2009), and to conserve native biodiversity, it will be critical to evaluate how species interactions are changing and what the impacts of novel interactions are for native species.

\section{MATERIALS AND METHODS}

\section{STUDY SPECIES AND SITES}

We examined four endemic species of Hawaiian lobelioids - Delissea waianaeensis, Cyanea grimesiana obatae, Cyanea longiflora, and Clermontia persicifolia. All of the species are endemic to the island of $\mathrm{O}$ 'ahu and three are critically endangered (Tab. 1). These forest understory plants all have hermaphroditic protandrous flowers, comprising either male or female floral stages, with plants exhibiting all male, all female, or a mix of male and female stage flowers at a given time (Lammers 2005, Lammers 1991). Flowers are all tubular, tetracyclic, fundamentally pentamerous, perfect, complete, dichogamous via proterandry, and epigynous. The five petals are bisymmetrically and bilabiate arranged, with a pair of dorsal petals and a trio of ventral petals. Stamens form a hollow staminal column around the style, and pollen dehisces longitudinally and introrsely, depositing pollen inside the column. A single style is present with a pair of stigmatic lobes at its apex. As the style extends, it pushes the pollen mass out of the staminal column, once extending past the column the lobes unfurl and become receptive to fertilization. When viewed from the side, the middle of the floral tube is higher in the middle then on the ends, leading to a "humpback" appearance (Lammers 2005).

We studied plants at three mesic forest sites in the Wai'anae Range of O'ahu, HI - Pahole Natural Area Reserve (2132'11.30"N 158 $10^{\circ} 47.64^{\prime \prime} \mathrm{W}$, hereafter PAH), Kahanāiki Management Unit $\left(21^{\circ} 32^{\prime} 12.55^{\prime \prime} \mathrm{N} 158^{\circ} 11^{\prime} 35.40^{\prime \prime} \mathrm{W}\right.$, hereafter $\left.\mathrm{KAH}\right)$, and 'Ēkahanui Gulch (2126'35.90"N 158 $5^{\circ} 4.27^{\prime \prime} \mathrm{W}$, hereafter EKA) (details on sites provided in (Vizentin-Bugoni et al. 2019). Plant communities at each site are novel, with over $30 \%$ of plant species being non-native. In particular, $30.4 \%$ of plant species are non-native at $\mathrm{PAH}, 40.2 \%$ are nonnative species at $\mathrm{KAH}$, and $92.9 \%$ of plants are non-native species at EKA (Vizentin-Bugoni et al. 2019). Furthermore, bird assemblages at our study sites comprise mostly non-native bird species (Vizentin-Bugoni et al. 2019). All observed plants occurred in restored populations, being initially grown at an off-site facility and then planted in forested areas (hereafter called out-planting plot) by land managers. We examined plants within 5 out-plantings located across sites ( 3 at PAH, 1 at 
$\mathrm{KAH}$, and 1 at EKA). Interactions with $D$. waianaeensis and C. grimesiana obatae were examined at all three study sites. Interactions with C. persicifolia were examined at $\mathrm{PAH}$ and $\mathrm{KAH}$, and interactions with $C$. longiflora were examined at PAH. Out-planting plots are continuously managed by the Army Natural Resources Program on O'ahu (ANRPO) and/or the State of Hawaii Department of Land and Natural Resources (DLNR).

\section{DETECTION OF INTERACTIONS}

We used two methods to detect interactions: inperson observations and game camera deployment. In-person observations were used to detect interactions with invertebrates, while game camera deployment was used to detect interactions with vertebrates. Both methods were used because some insects in our system are quite small (e.g., yellow-faced bees) and may fail to trigger game cameras during every visit. However, game cameras are reliable for larger taxa and are capable of detecting night-time visitation (Rowcliffe et al. 2011).

We conducted in-person observations of flowering plants at all three sites from May - July 2019. During observations, a single observer with binoculars was positioned 3 meters from the focal plant. In each interaction, we recorded the animal species (to family or genus), the sex of flower visited, whether the animal made contact with reproductive structures, and whether the animal entered floral tubes. In-person observations were conducted for one-hour intervals during daylight hours (8:00 to 17:00), with a median observation time of 11:00. In total, observation times were 11 hours ( $N=7$ plants) for $D$. waianaeensis, 10 hours $(N$ $=6$ plants) for $C$. grimesiana obatae, and 7 hours $(N$ $=2$ plants) for $C$. persicifolia. No plants were observed more than once on a given day. Owing to logistical constraints and the rarity of these plants, we monitored few individuals, and we were not able to choose only focal plants spatially segregated from each other. Further, individual plants from different focal species were sometimes monitored within the same out-planting locations. From all species examined, focal plants ranged from $1-23,053 \mathrm{~m}$ apart $($ mean $=7,951 \mathrm{~m}$, median $=$ 9,883 $\mathrm{m}$ ), and 2-9 plants (across all plant species examined) were observed per out-planting plot (median $=5$ ). Owing to the timing of flowering, we were unable to conduct in-person observations of C. longiflora and only obtained data on this species from game cameras (see below). Even with small sample sizes of in-person observations, our results indicate high variation in the pollinator community, and this work should serve as a starting point for future studies.

Game cameras were deployed on flowering plants at all three sites from April - September 2019, and February - April 2017 and 2018 Specifically, we used the Bushnell Trophy Camera Brown Model 119836, programmed to record videos for 10-15 seconds following motion detection for 24 hours/day. Cameras were placed within 1 meter of the focal plant for a duration of 6 to 54 days per plant (median: 14 days). We deployed game cameras on $D$. waianaeensis $(N=14$ plants for 5,688 hours), C. grimesiana obatae ( $N=7$ plants for 19,364 hours), C. persicifolia ( $N=7$ plants for 2,640 hours), and C. longiflora ( $N=6$ plants for 2,352 hours). Some individual plants were monitored simultaneously using both in-person observations and game camera deployment $(N=5$ plants for $D$. waianaeensis, $N=6$ plants for $C$. grimesiana obatae, and $N=2$ plants for $C$. persicifolia).

\section{CLASSIFICATION OF INTERACTIONS}

We defined three types of interactions reproductive contact, nectar larceny, and visitation - based on the behaviour of the visitor at focal flowers. Events in which animals made contact with reproductive structures (stigma or pollen brush at the tip of the staminal column) were recorded as reproductive contact, whereas events in which animals took nectar or entered floral tubes without touching reproductive structures were recorded as nectar larceny (Inouye 1980). In particular, we defined bird interactions as reproductive contact when a bird inserted its bill into a flower in such a way that the feathers on its head or body came into contact with the reproductive structures of the flower. We defined bee reproductive contact as occurring when bees landed on the reproductive structures (stigma or pollen brush depending on stage of flower). We defined bird nectar larceny as occurring when a bird accessed nectar reserves without making contact with reproductive structures, occurring when a bird inserted its bill into the front or back of the flower, often through a hole in the base of the flower. We defined bee nectar larceny as 
occurring when a bee entered the floral tube without making contact with reproductive structures. Visitation events occurred when there was physical contact between animals and flowers, irrespective of whether the animal was feeding on nectar, collecting pollen, or only making physical contact with flowers without collection of nectar or pollen. Among visitation events, feeding visits occurred when animals were observed feeding on or collecting pollen or nectar. Each instance of contact between an animal and flower was recorded as a separate visitation.

\section{FOCAL AND NEIGHBOURHOOD CHARACTERISTICS}

For plants monitored between May-July 2019 ( $N=38$ plants), we recorded focal plant data and conducted vegetation surveys of the surrounding neighbourhood ( $N=116$ vegetation surveys). For plants with game camera deployment, surveys were conducted on each plant every 14-21 days ( mean $=15.7$, median $=14$ ) owing to likely changes in the number of flowers on focal plants and in the floral community over time. If we conducted an inperson observation on a plant without game camera deployment, we conducted a vegetation survey immediately before the in-person observation. In each survey, we recorded the number of flowers and sex of each flower on focal plants. From all vegetation surveys $(N=46$ vegetation surveys from 38 plant individuals), 20 plants had all male flowers, 8 had all female flowers, and 18 had a mix of female and male flowers. In total, 169 male flowers and 100 female flowers were observed on the 38 plants. We also identified the species of all flowering plants and counted the number of open flowers for each species in the surrounding neighbourhood. We defined the neighbourhood as a $7 \mathrm{~m}$ radius surrounding each focal plant. We chose a $7 \mathrm{~m}$ radius because we expected that plants within this range could be perceived by animals (both birds and bees) and a greater radius would introduce more potential for perceptual obstruction by the dense vegetation. Furthermore, a $7 \mathrm{~m}$ radius is similar in size to other neighbourhood studies (Sargent 1990; Saracco et al. 2005; Smith \& McWilliams 2014; Hopson et al. 2020). For our metrics of the number of focal plant flowers, conspecific flowers, and heterospecific flowers, we took the average number of flowers observed between two consecutive vegetation surveys to account for changes in the number of flowers over time, providing a single value for each observation interval. Upon camera setup, we measured canopy cover over focal plants using a spherical crown densiometer, positioned directly over the focal plant during measurement.

\section{StATISTICAl ANALySES}

For all analyses we tested different random effects structures (out-planting plot within a given site, plant ID), and used the one that explained the greatest variance in the model. We did not perform model selection, other than removing correlated variables or ones due to sample size constraints, meaning our results are based on the global models listed below. All analyses were performed in Program R 3.6.1 (R Development Core Team, 2019).

We created animal group-specific models to examine how characteristics of the neighbourhood and traits of the focal plant influenced the probability of visitation or the number of visits. Fixed effects of interest included the number of flowers on the focal plant, the number of conspecific flowers in the neighbourhood, the number of heterospecific flowers in the neighbourhood, percent of non-native flowers in the neighbourhood, and percent canopy cover. The percent of non-native flowers and the number of heterospecific flowers were highly correlated (0.8); therefore, we removed the percent of non-native flowers from all models. We conducted two separate models, the bee visitation model which was based on our in-person observations and a bird visitation model which was based on our game cameras. We conducted two separate analyses because the game cameras could not detect the smaller, native bees, while birds did not visit during in-person observations.

For the bee visitation model, we used the inperson observation data. Owing to a small sample size, we were only able to examine the probability of visitation, rather than what influenced the number of visits. We used a GLMM with a binomial error structure, a logit link function, and visitation (yes, no) as the response variable. Only half of our plants had canopy cover measures taken; thus, we first examined whether canopy cover influenced the probability of bee visitation, and because we found that it did not, we removed canopy cover from subsequent analyses to increase 
sample size $(N=28$ hours of observation from 15 individual plants). Our global model included the number of focal flowers, number of heterospecific flowers, and number of conspecific flowers as fixed effects, and out-planting plot as the random effect.

For bird visitation models, we used data from game camera traps, and we conducted two separate analyses owing to the data being zeroinflated (e.g., $67 \%$ of observation intervals had no visitors, and few observations with more than one visit, Zuur et al. 2010). First, we examined the probability of visitation using a GLMM with a binomial error structure, a clog-log link function, and the response variable was visitation (yes, no). Second, we examined the number of visits, given at least one visit was observed, using a GLM with a negative binomial error structure, a log link function, and the response variable was number of visits. Unlike the in-person observations, game cameras were placed on focal plants for variable lengths of time and we accounted for this in both models (see below). For the probability of visitation model, we tested a separate model for canopy cover and removed it from subsequent analyses because it did not influence the probability of visitation. Therefore, our global model included the average number of flowers on the focal plant, average number of conspecific flowers, average number of heterospecific flowers, and number of days the plant was filmed as fixed effects, and out-planting plot as a random effect $(N$ $=49$ observation intervals) from 27 plants, with an average of 1.8 observation intervals per plant). For the number of visits model, we broke this down into separate models for each variable of interest owing to the small sample size for the number of plants visited one or more times $(N=20$ observation intervals). Each model had an offset of the number of days a plant was filmed, and then a fixed effect of either average number of focal flowers, average number of conspecific flowers, average number of heterospecific flowers, or canopy cover. Owing to the small sample size, the potential random effects of plant ID and outplanting plot did not explain any variation, and therefore, were not retained.

\section{RESULTS}

\section{VISITING SPECIES}

Although flowers were visited by both native and non-native species, the native $\mathrm{O}$ 'ahu 'amakihi (Chlorodrepanis flava) was the most frequent bird visitor and the yellow-faced bee was the most frequent bee visitor (Tab. 2). We observed floral

Table 2. Floral visitation by each species and percent of feeding visits (nectar larceny or contact with reproductive structures) or non-feeding visits, which includes visits where animals made physical contact with flowers but did not take nectar nor make contact with reproductive structures.

\begin{tabular}{|c|c|c|c|c|c|c|}
\hline $\begin{array}{l}\text { Animal } \\
\text { group }\end{array}$ & Species & Native status & $\begin{array}{r}\text { Total } \\
\text { visitations }\end{array}$ & $\begin{array}{r}\text { Nectar } \\
\text { larceny }(\%)\end{array}$ & $\begin{array}{l}\text { Contact with } \\
\text { reproductive } \\
\text { structures (\%) }\end{array}$ & $\begin{array}{r}\text { Non- } \\
\text { feeding } \\
\text { visits (\%) }\end{array}$ \\
\hline \multirow[t]{5}{*}{ Bird } & O'ahu ‘amakihi & Native & 621 & 96.3 & 0.0 & 3.7 \\
\hline & (Chlorodrepanis flava) & & & & & \\
\hline & $\begin{array}{l}\text { Warbling white-eye (Zosterops } \\
\text { japonicus) }\end{array}$ & Non-Native & 103 & 84.4 & 3.9 & 11.7 \\
\hline & 'Apapane (Himatione sanguinea) & Native & 13 & 100.0 & 0.0 & 0.0 \\
\hline & Red-billed leiothrix (Leiothrix lutea) & Non-Native & 2 & 0.0 & 50.0 & 50.0 \\
\hline Mammal & Rat (Rattus sp.) & Non-Native & 16 & 0.0 & 75.0 & 25.0 \\
\hline \multirow[t]{5}{*}{ Insect } & Yellow-faced bee (Hylaeus sp.) & Native & 88 & 2.3 & 71.6 & 26.1 \\
\hline & Western honey bee (Apis mellifera) & Non-Native & 55 & 14.5 & 50.9 & 34.6 \\
\hline & Ant (Formicidae sp.) & Non-Native & 3 & 100.0 & 0.0 & 0.0 \\
\hline & Moth (larva) (Lepidoptera sp.) & Unknown & 1 & 0.0 & 0.0 & 100.0 \\
\hline & Hoverfly (Syrphidae sp.) & Unknown & 1 & 0.0 & 0.0 & 100 \\
\hline
\end{tabular}


Table 3. Visitation rates per hour to individual plants by (a) bees and (b) birds for each plant species. For bees, visitation rates are based on in-person observations and for birds, visitation rates are based on game cameras.

\begin{tabular}{|c|c|c|c|c|}
\hline Animal group & Plant species & $\begin{array}{r}\text { Mean visitation } \\
\text { rate (visits/hr) }\end{array}$ & $\begin{array}{r}\text { Plants } \\
\text { sampled }\end{array}$ & Hours sampled \\
\hline \multirow[t]{3}{*}{ (a) Bees } & Clermontia persicifolia & 2.000 & 2 & 7 \\
\hline & Cyanea grimesiana obatae & 1.900 & 6 & 10 \\
\hline & Delissea waianaeensis & 1.818 & 7 & 11 \\
\hline \multirow[t]{4}{*}{ (b) Birds } & Clermontia persicifolia & 0.003 & 5 & 1,365 \\
\hline & Cyanea grimesiana obatae & 0.103 & 10 & 6,253 \\
\hline & Cyanea longiflora & 0.000 & 5 & 1,547 \\
\hline & Delissea waianaeensis & 0.020 & 15 & 4,446 \\
\hline
\end{tabular}

visitations by the O'ahu 'amakihi (Chlorodrepanis flava), warbling white-eye (Zosterops japonicus), 'apapane (Himatione sanguinea), red-billed leiothrix (Leiothrix lutea), rat (Rattus sp.), yellow-faced bee (Hylaeus sp.), western honey bee (Apis mellifera), ant (Formicidae sp.), moth larvae (Lepidoptera sp.), and hoverfly (Syrphidae sp.) (Tab. 2). Rats could not be identified to species from video footage, but potential species include the black rat (Rattus rattus), Norway rat (Rattus norvegicus), and Pacific rat (Rattus exulans) (Pratt et al. 2009; Shiels and Drake 2011). In visitations captured by game cameras $(N=847), 73.3 \%$ were by the O'ahu 'amakihi, $12.1 \%$ by the warbling white-eye, $6.5 \%$ by the western honey bee, $4.1 \%$ by the yellowfaced bee, $1.9 \%$ by rats, $1.5 \%$ by the 'apapane, $0.2 \%$ were unknown insects, and $0.002 \%$ by the redbilled leiothrix. In visitations observed in-person $(N=59), 91.5 \%$ were by yellow-faced bees, $5.08 \%$ by ants (Formicidae sp.), $1.6 \%$ by moth larva (Lepidoptera sp.), and $1.6 \%$ by hoverflies (Syrphidae $\mathrm{sp}$.). Of the flowers visited by bees during the inperson observations $(N=40), 73 \%$ of visits were on male flowers and $27 \%$ were on female flowers ( 55 male and 22 female flowers were observed in total). Overall, bees visited flowers far more frequently than birds, with bees visiting flowers on average 1.89 visits/hour and birds visiting flowers on average 0.05 visits/hour (Tab. 3).

Visitation varied amongst the different plant species, with visitations ranging from $0-2.6$ visits/hr (Tab. 3). One plant species, C. longiflora, was never visited by any species, while $C$. persicifolia, the species that is of lower conservation concern out of the four plant species, received the highest visitation rate out of all plant species.

REPRODUCTIVE STRUCTURE CONTACT AND NECTAR LARCENY
Bees contacted reproductive structures in $90.6 \%$ of their feeding interactions, whereas birds contacted reproductive structures in only $0.7 \%$ of feeding visits. In particular, from a total of 106 feeding visits by bees, 96 involved landing upon reproductive structures (Fig. 1), and 10 involved nectar larceny, whereby bees crawled into floral tubes without damaging tissues. Birds contacted reproductive structures in only 5 of the 703 feeding visits observed. Birds appeared to be primarily nectar robbers, damaging floral tissues. In particular, while feeding, birds would perch at the base of the flower, and they either created small holes or used previously created holes with their bills in the bottom of the corolla (as opposed to entering the floral tube opening). Birds also split the corolla using their bills while positioned from above, allowing them access to the nectar without touching reproductive structures (Fig. 1).

FOCAL AND NEIGHBOURHOOD CHARACTERISTICS INFLUENCINC VISITATION

Characteristics of the focal plant and/or the neighbourhood influenced visitation, with both bees and birds increasing their probability of visitation when the focal plant had more flowers (Tab. 4, Fig. 2A-B). For bees and birds, only the number of flowers on the focal plant influenced the probability of visitation, while the number of conspecific or heterospecific flowers in the surrounding neighbourhood did not (Tab. 4). For birds, we found that characteristics of the focal plant and the neighbourhood influenced the number of visits to a focal plant, given that a bird visited at least once (Tab. 4, Fig. 2C-F). In particular, we found increased visitation to focal plants with an increased number of flowers on focal plants and an increased number of 


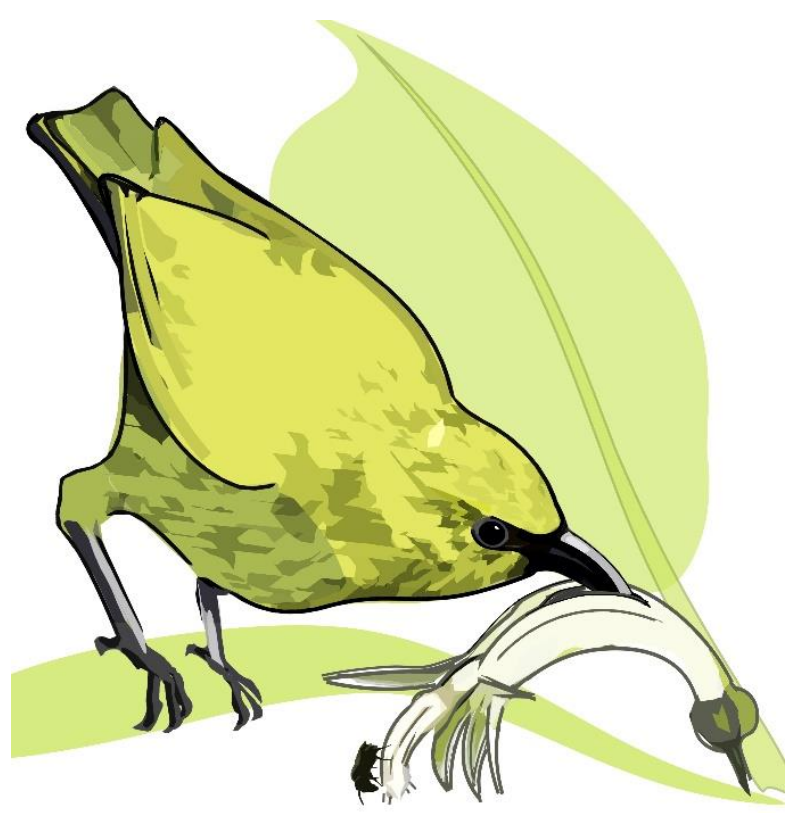

Figure 1. Illustration of a Delissea waianaeensis flower with nectar larceny by $O$ 'ahu 'amakihi (Chlorodrepanis flava) and contacting pollen by yellow-faced bees (Hylaeus sp.).

conspecific flowers in the neighbourhood (Fig. 2CD). In contrast, a greater number of heterospecific flowers in the neighbourhood decreased the number of visits, although effects were marginal (Tab. 4, Fig. 2E). Lastly, we found that increased canopy cover increased the number of visits by birds (Tab. 4, Fig. 2F).

\section{Discussion}

In the Hawaiian Islands, at least 134 plant species (Wood et al. 2019) and 79 bird species have gone extinct since human arrival (T. K. Pratt et al. 2009). Hawaiian lobelioids, which are renowned for exemplifying coevolutionary processes with avian nectarivores, have been disproportionately affected, with $25 \%$ of species extinct and many extant species presently at-risk of extinction (Smith et al. 1995). Although Hawaiian lobelioids exhibit floral traits adapted for historic bird pollinators (Givnish et al. 2009; Pender et al. 2014), in novel forest ecosystems of $\mathrm{O}^{\prime} \mathrm{ahu}$, we found that birds of modern forests were unlikely to transfer much pollen between lobelioid plants, owing to low floral visitation and infrequent contact with reproductive structures. In contrast, bees were more likely to transfer pollen, owing to more frequent visitation and contact with flowers in both male and female stages of development. Thus, bees are likely to be more important than birds for maintaining pollination in the at-risk lobelioid species we examined, while the effects of nectar larceny by birds on bee pollination remains largely unexplored. Other animal groups had low visitation rates. For example, rats infrequently visited flowers ( $N=16$ visits), during which they consumed floral tissues, likely destroying entire flower structures. Nevertheless, further research is

Table 4. Model results for predictors affecting (a) the probability of bee visitation, (b) the probability of bird visitation, and (c) number of bird visits.

\begin{tabular}{|c|c|c|c|c|}
\hline Model & Predictor & $\beta$ & SE & P-value \\
\hline \multicolumn{5}{|c|}{ (a) Probability of bee visitation $\left(\mathbf{R}^{2}=0.54\right)$} \\
\hline & Number of flowers on focal plant & 1.88 & 1.01 & 0.06 \\
\hline & Number of conspecific flowers in neighborhood & -0.44 & 0.65 & 0.50 \\
\hline & Number of heterospecific flowers in neighborhood & 0.03 & 1.08 & 0.98 \\
\hline \multicolumn{5}{|c|}{ (b) Probability of bird visitation $\left(\mathbf{R}^{2}=\mathbf{0 . 7 4}\right)$} \\
\hline & Number of flowers on focal plant & 1.04 & 0.55 & 0.06 \\
\hline & Number of conspecific flowers in neighborhood & -1.01 & 0.93 & 0.28 \\
\hline & Number of heterospecific flowers in neighborhood & 0.62 & 0.59 & 0.30 \\
\hline & Number of days filmed & 0.65 & 0.52 & 0.21 \\
\hline \multicolumn{5}{|c|}{ (c) Univariate models* } \\
\hline & (1) Number of flowers on focal plant $\left(\mathbf{R}^{2}=\mathbf{0 . 8 3}\right)$ & 0.91 & 0.32 & $<0.01$ \\
\hline & (2) Number of conspecific flowers in neighborhood $\left(\mathbf{R}^{2}=\mathbf{0 . 7 4}\right)$ & 2.79 & 0.97 & $<0.01$ \\
\hline & (3) Number of heterospecific flowers in neighborhood $\left(\mathbf{R}^{2}=\mathbf{0 . 9 0}\right)$ & -0.41 & 0.23 & 0.08 \\
\hline & (4) Percentage of canopy cover above focal plants $\left(R^{2}=0.65\right)$ & 3.26 & 0.95 & $<0.01$ \\
\hline
\end{tabular}

*All four models included an offset of the number of days the plant was filmed. 

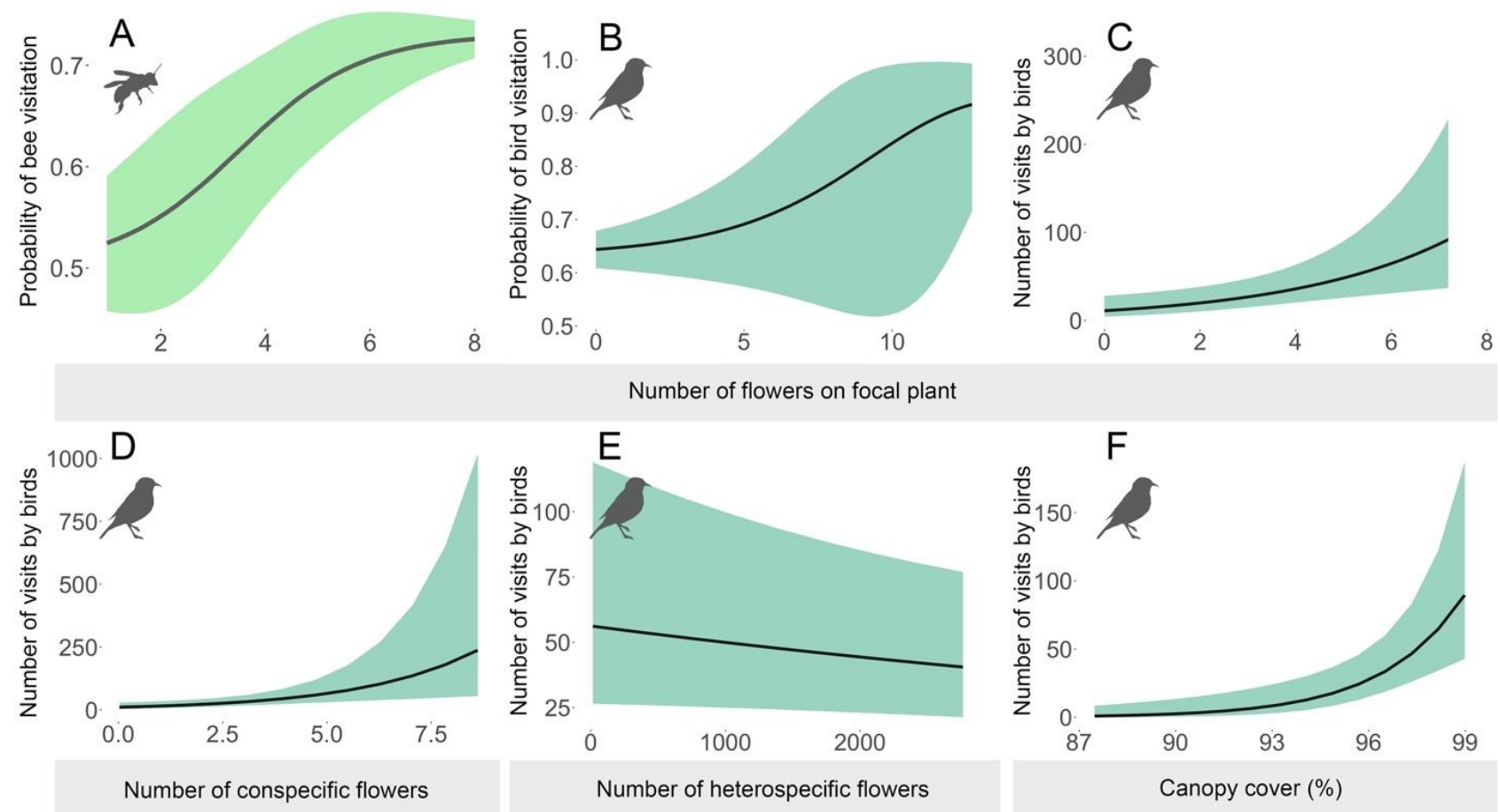

Figure 2. Model results from bird and bee visitation models, with the number of flowers on the focal plant affecting (A) the probability of bee visitation, (B) the probability of bird visitation, and (C) the number of visits by birds. The number of visits by birds was influenced by (D) the number of conspecific flowers, $(E)$ the number of heterospecific flowers, and (F) the percentage of canopy cover. The green shading is the $95 \%$ Cls from the model output.

needed to assess the impacts of these infrequent visitors. Furthermore, native and non-native species appeared to have similar effects on the flowers (potential for either pollination or larceny). Thus, the more frequent visitation by native species, compared to non-native species, to lobelioids did not necessarily lead to more pollination. We showed that characteristics of the focal plant and the surrounding neighbourhood altered bird and bee visitation. Because Hawaiian lobelioids are often out-planted strategically by land-managers (James 2009), the manipulation of these characteristics could improve conservation strategies. More broadly, our results demonstrate that in novel ecosystems, both native and nonnative species may help fill the functional role of extinct species.

\section{NECTAR LARCENY BY BIRDS}

We recorded visitation to lobelioids by two native bird species, the 'apapane and $\mathrm{O}^{\prime}$ ahu 'amakihi, and two non-native bird species, the warbling white-eye and red-billed leiothrix (Tab. 2). However, pollination was unlikely; instead, birds were mostly committing nectar larceny. Nectar larceny by birds generally occurs in specialized flowers with long floral tubes that are difficult for birds with small bills to reach (RojasNossa et al. 2016). In our study, bird species had small bills (13.12 - $16.66 \mathrm{~mm}$ culmen length, (Gleditsch \& Sperry 2019) compared to the floral tube lengths of the lobelioid species we examined (45 - $90 \mathrm{~mm}$ corolla length) (Wagner et al. 1999). Previous studies have reported nectar larceny of Hawaiian lobelioids by warbling white-eye and O'ahu 'amakihi (Gardener \& Daehler 2006, Aslan et al. 2014). To our knowledge, we are the first to describe nectar larceny by 'apapane on lobelioids (Tab. 2). O'ahu 'amakihi and 'apapane are known to feed upon nectar of other native plants (Pratt et al. 2010) and our work indicates nectar from lobelioid flowers is another food resource for the remaining native birds. Nevertheless, as found in other studies on the Hawaiian Islands, we found that bird visitation to lobelioids was infrequent (Lammers et al. 1988). Therefore, we would expect that the impact of nectar larceny by birds on legitimate pollination is low, but given the high abundance and widespread distribution of these birds in Hawaii (BirdLife International 2017), future work should examine whether nectar larceny by these species impacts pollination of Hawaiian plants. 


\section{REPRODUCTIVE CONTACT BY BEES}

We found that both native yellow-faced bees and non-native western honey bees visited plants frequently and made contact with reproductive structures during visits to the three lobelioid species (D. waianaeensis, C. grimesiana obatae, and C. persicifolia) we observed in-person. The majority of observed bee visits (all in-person observations) were by yellow-faced bees. In Hawai'i, yellowfaced bees carry less pollen but exhibit higher pollinator fidelity compared to western honeybees, and western honeybees often forage on pollen of invasive plants (Miller et al. 2015). Thus, yellow-faced bees are expected to be more effective pollinators of native plants compared to western honeybees, but more research is needed to compare bee species (Miller et al. 2015). Future studies should, for instance, examine pollinator effectiveness on different plants and for different bee species, considering pollinator fidelity and movement patterns. Yellow-faced bees have been observed visiting flowers of two other lobelioid species on O'ahu (Gardener \& Daehler 2006). We found that bees visited both male and female flower phases, suggesting that pollination events are likely occurring. We also detected nectar larceny in $2.3 \%$ of visits by yellow-faced bees. Although nectar larceny by yellow-faced bees has not been previously reported, nectar larceny is common in other bee species (Roubik 1982; Hanna et al. 2013). At least 63 endemic yellow-faced bee species are known, 33 of which are species of conservation concern, and 7 species are listed as endangered by the United States Fish and Wildlife Service (Daly \& Magnacca 2003; Fish and Wildlife Service 2016). Because they tend to specialize on few flowering plant species (Wilson et al. 2010), lobelioid pollen and nectar may be a critical food resource for some yellow-faced bee populations.

VISITATION AND INFLUENCE OF THE FOCAL PLANT AND NEIGHBOURHOOD

Floral visitation is highly variable across ecosystems worldwide and may depend on factors ranging from site-level characteristics to features of entire biogeographic regions (Primack \& Inouye 1993; Ollerton et al. 2009). Novel ecosystems may be particularly susceptible to changes in floral visitation from loss or gain of pollinator species (Ollerton et al. 2009). In our system, visitation was low for all plants examined, but bees visited lobelioids much more frequently than birds. Thus, the overall impact of bees on lobelioid populations is likely greater than impacts from birds. Because all lobelioids examined are of conservation concern, low visitation rates suggest potential for pollination limitation as a threat to remaining populations. For instance, one plant species, Cyanea longiflora, received zero visitation. Owing to low visitation rates in bees and nectar-robbing by birds, the functional roles of extinct lobelioid pollinators are unlikely being completely substituted by animals in modern forests.

Characteristics of the focal plant and the neighbourhood influenced visitation by birds and bees suggesting that these traits alter the probability of detecting and visiting a plant. In particular, bird and bee visitation increased when there were more flowers on the focal plant, likely owing to a larger visual signal to animals and the potential for higher rewards (Baude et al. 2011). Furthermore, bird visitation increased with increased canopy cover and conspecific flowers in the neighbourhood, while decreasing with increased heterospecific flowers in the neighbourhood. Increased canopy cover increases perching locations, reduces temperatures, and may improve visual cues by shading flowers, all of which may increase the amount of time birds spend in these areas (Primack \& Inouye 1993, Altshuler 2003, Champlin et al. 2009, Hopson et al. 2020). Further, we expect that floral density of conspecific and heterospecific plants surrounding focal plants serves as a visual cue for birds, affecting selection of foraging patches and individual plants within foraging patches (Sargent 1990). Conspecific flowers in the neighbourhood may facilitate interactions with focal plants by cueing in nectarivores to lobelioid nectar (Elliott \& Irwin 2009). In contrast, heterospecific flowers in the neighbourhood may decrease bird visitation due to interspecific competition between plants (Totland et al. 2006; Bruckman \& Campbell 2014). Further work is needed to evaluate floral neighbourhood relationships in our system and the behaviours of different visiting species.

\section{ISLAND ECOSYSTEMS AND THE INTRODUCTION OF NON-NATIVE FLORAL VISITORS}

Island ecosystems are particularly vulnerable to species extinction and invasion, and the introduction of non-native pollinators can have 
varying effects on pollination processes (Traveset \& Richardson 2006). Pollination success generally declines for native flora following the extinction of historic pollinators and introduction of non-native pollinators, owing to differences in the roles of species lost and gained (Traveset \& Richardson 2006; Mortensen et al. 2008). For instance, on both New Zealand and Guam, where many or all native pollinators have gone extinct, a suite of new species pollinate native plants, but seed set, fruit production, and juvenile recruitment are lower in these novel communities compared to intact communities nearby (Lord 1991; Mortensen et al. 2008; Kelly et al. 2010; Anderson et al. 2011; Pattemore \& Wilcove 2012). Non-native bees, in particular, have the potential to substitute vacant pollinator roles or disrupt interactions between native pollinators and native flora. For instance, non-native honeybees substitute roles of extinct or declining native bee populations in the Ogasawara Islands and Bonin Islands (Kato et al. 1999; Abe et al. 2011). However, in New Caledonia and Australia, non-native bees have disrupted pollination by native fauna by removing the majority of pollen from native flora (Whelan et al. 2001; Kato \& Kawakita 2004). Furthermore, following the extinction or population decline of avian pollinators in island ecosystems, bees often shift into dominant pollinator roles for historically bird-pollinated flora (Rosas-Guerrero et al. 2014). For example, in New Zealand, a mistletoe species that was historically bird-pollinated, now has two native bee species (Hylaeus spp. and Leioproctus spp.) that appear to pollinate the species (Robertson et al. 2005). Therefore, shifts in both the status of the pollinator (native vs. non-native) and the taxonomic group (e.g., birds vs. bees) have been observed on islands, with differential impacts on native plants.

The Hawaiian Islands have experienced high rates of pollinator extinction and introduction (Junker et al. 2010; Hanna et al. 2014; Aslan et al. 2016; Shay et al. 2016). Previous work has shown that, like other island systems, non-native birds and insects contribute to the maintenance of pollination processes for some native plant species, but they are unlikely to fully substitute the roles of lost pollinators (Walsh et al. 2019). Intact populations of native yellow-faced bees are currently maintaining pollination for many endemic plant communities (Wilson et al. 2010;
Koch \& Sahli 2013) and for certain plant populations, non-native western honeybees may play a critical role in pollination (Junker et al. 2010). In our study, we found that Hawaiian lobelioids that have lost their historic bird pollinators may now depend on native and nonnative bees for pollination services, and the modern bird community, composed of native and non-native species, may either have no impact or negatively impact plants by stealing nectar. Thus, our findings suggest that, in relation to impacts on native flora, the taxonomic grouping (bird or bee) of the floral visitor is more important than whether or not the organism is native to the ecosystem.

Major shifts in plant-animal interactions following species extinction and introduction have likely contributed to observed population declines in lobelioids and may continue to impact the distribution and abundance of remaining populations into the future. Further, shifts in the visiting species may have differing effects on plant population fitness, which may impact the demography and evolutionary trajectories for lobelioids species over time (Zhang et al. 2007; Castro et al. 2008). Ultimately, increased understanding of how critical plant-animal interactions are responding to species extinctions and introductions will improve efforts to conserve native species in a rapidly changing world.

\section{ACKNOWLEDGEMENTS}

This work was funded by Wyoming Nasa Space Grant Consortium, NASA Grant \#NNX15AI08H. Our research was also supported by the Strategic Environmental Research and Development Program (SERDP) and the U.S. Army Corps of Engineers. We thank undergraduate and graduate students in the Tarwater lab at the University of Wyoming for discussion pertaining to this work, and D. Drake for providing helpful feedback on the manuscript. Further, we thank R. Tam for assistance with data collection. This is publication no. 12 of the Hawaii VINE (Vertebrate Introductions and Novel Ecosystems) Project.

\section{REFERENCES}

Abe T, Wada K, Kato Y, Makino S, Okochi I (2011) Alien pollinator promotes invasive mutualism in an insular pollination system. Biological Invasions 13:957-967. https://doi.org/10.1007/s10530-010-9882-9

Altshuler DL (2003) Flower Color, Hummingbird Pollination, and Habitat Irradiance in Four Neotropical Forests. Biotropica 35:344-355 
Anderson SH, Kelly D, Ladley JJ, Molloy S, Terry J (2011) Cascading Effects of Bird Functional Extinction Reduce Pollination and Plant Density. Science 331:1068-1071. https://doi.org/10.1126/science.1199092

Aslan CE, Liang CT, Galindo B, Hill K, Topete W (2016) The Role of Honey Bees as Pollinators in Natural Areas. Natural Areas Journal 36:478-488. https://doi.org/ $\underline{10.3375 / 043.036 .0413}$

Aslan CE, Zavaleta ES, Tershy B, Croll D, Robichaux R (2014b) Imperfect replacement of native species by non-native species as pollinators of endemic Hawaiian plants. Conservation Biology 28:478-488. https://doi.org/10.1111/cobi.12193

Baude M, Danchin É, Mugabo M, Dajoz I (2011) Conspecifics as informers and competitors: An experimental study in foraging bumble-bees. Proceedings of the Royal Society B: Biological Sciences 278:2806-2813. https://doi.org/10.1098/rspb.2010.2659

BirdLife International (2017) Himatione sanguinea. The IUCN Red List of Threatened Species 2017: e.T103828426A111174421. http://dx.doi.org/10.2305/ IUCN.UK.2017-1.RLTS.T103828426A111174421.en

Bond WJ (1994) Do mutualisms matter? Assessing the impact of pollinator and disperser disruption on plant extinction. Philosophical Transactions - Royal Society of London, B 344:83-90. https://doi.org/10.1098/ rstb.1994.0055

Boyer AG (2008) Extinction patterns in the avifauna of the Hawaiian Islands. Diversity and Distributions 14:509-517. 4642.2007.00459.x

Bruckman D, Campbell DR (2014) Floral neighbourhood influences pollinator assemblages and effective pollination in a native plant. Oecologia 176:465-476. https://doi.org/10.1007/s00442-014-3023-6

Castilla AR, Pope NS, O'Connell M, Rodriguez M, Treviño L, Santo A, Jha S (2017) Adding landscape genetics and individual traits to the ecosystem function paradigm reveals the importance of species functional breadth. Proceedings of the National Academy of Sciences of the United States of America 114:1276112766. https://doi.org/10.1073/pnas.1619271114

Castro S, Silveira P, Navarro L (2008) Consequences of Nectar Robbing for the Fitness of a Threatened Plant Species. Plant Ecology 199:201-208. https://doi.org/10.1007/s1l258-008-9424-Z

Champlin TB, Kilgo JC, Gumpertz ML, Moorman CE (2009) Avian response to microclimate in canopy gaps in a bottomland hardwood forest. Southeastern Naturalist 8:107-120. https://doi.org/10.1656/058.008.0110

Conner JK, Rush S (1996) Effects of Flower Size and Number on Pollinator Visitation to Wild Radish, Raphanus raphanistrum. Oecologia 105:509-516
Cory C, Pender R, Jones CE (2015) Can Ornithophilous Hawaiian Lobeliads Produce Seeds in the Absence of Pollinators? A Test Using Clermontia kakeana and Cyanea angustifolia (Campanulaceae). Pacific Science 69:255-261. https://doi.org/10.2984/69.2.7

Cox PA (1983) Extinction of the Hawaiian Avifauna Resulted in a Change of Pollinators for the ieie, Freycinetia arborea. Oikos 41:195-199

Daly H, Magnacca K (2003) Insects of Hawaii (VOL. 17). University of Hawai i Press, Honolulu.

Eckhart VM (1991) The effects of floral display on pollinator visitation vary among populations of Phacelia linearis (Hydrophyllaceae). Evolutionary Ecology 5:370384

Elliott SE, Irwin RE (2009) Effects of flowering plant density on pollinator visitation, pollen receipt, and seed production in Delphinium barbeyi (Ranunculaceae). American Journal of Botany 96:912-919. https://doi.org/10.3732/ajb.0800260

Elphick CS, Roberts DL, Michael Reed J (2010) Estimated dates of recent extinctions for North American and Hawaiian birds. Biological Conservation 143:617-624. https://doi.org/10.1016/j.biocon.2009.11.026

Fish and Wildlife Service (2016) Endangered and Threatened Wildlife and Plants; Endangered Status for 49 Species from the Hawaiian Islands. Federal Register 81:67786-67860

Freed LA, Medeiros MCI, Cann RL (2016) Multiple Reversals of Bill Length over 1. 7 Million Years in a Hawaiian Bird Lineage. The American Naturalist 187: https://doi.org/10.1086/684787

Gardener MC, Daehler CC (2006) Documenting floral visitors to rare Hawaiian plants using automated video recordings. Pacific Conservation Biology 12:189-194

Ghazoul J (2005) Pollen and seed dispersal among dispersed plants. Biological Reviews of the Cambridge Philosophical Society 80:413-443. https://doi.org/10.1017/S1464793105006731

Givnish TJ, Millam KC, Mast AR, Paterson T, Theim T, Hipp A, Henss J, Smith J, Wood K, Sytsma K (2009) Origin, adaptive radiation and diversification of the Hawaiian lobeliads (Asterales: Campanulaceae). Proceedings of the Royal Society B: Biological Sciences 276:407-416. https://doi.org/10.1098/rspb.2008.1204

Gleditsch JM, Sperry JH (2019) Rapid morphological change of nonnative frugivores on the Hawaiian island of $\quad \mathrm{O}^{\prime} \mathrm{ahu}^{*}$. Evolution 73:1456-1465. https://doi.org/10.1111/evo.13744

Hanna C, Foote D, Kremen C (2014) Competitive impacts of an invasive nectar thief on plant - pollinator mutualisms Author. Ecology 95:1622-1632

Hanna C, Foote D, Kremen C (2013) Invasive species management restores a plant-pollinator mutualism in 
Hawaii. Journal of Applied Ecology 50:147-155. https://doi.org/10.1111/1365-2664.12027

Harder LD, Barrett SCH (1995) Mating cost of large floral displays in hermaphrodite plants. Nature 373:512-515

Hobbs RJ, Higgs E, Harris JA (2009) Novel ecosystems: implications for conservation and restoration. Trends in Ecology and Evolution 24:599-605. https://doi.org/10.1016/j.tree.2009.05.012

Hopson RM, Wilcox RC, Tarwater CE (2020) Frugivores vary in their response to neighbourhood effects in a novel ecosystem. Acta Oecologica 108:103641. https://doi.org/10.1016/j.actao.2020.103641

Inouye DW (1980) The Terminology of Floral Larceny. Ecological Society of America 61:1251-1253

Irwin RE, Brody AK, Waser NM (2001) The impact of floral larceny on individuals, populations, and communities. Oecologia 129:161-168. https://doi.org/ $\underline{10.1007 / s 004420100739}$

Irwin RE, Bronstein JL, Manson JS, Richardson L (2010) Nectar Robbing: Ecological and Evolutionary Perspectives. Annual Review of Ecology, Evolution, and Systematics 41:271-292. $\quad$ https://doi.org/10.1146/annurev.ecolsys.110308.120330

James SA (2009) Final report. Population genetics of Delissea waianaeensis Lammers (Campanulaceae) and parental identification of a potential new founder individual. Report prepared for U.S. Army, O'ahu Army Natural Resource Program, Schofield Barracks, Hawaii.

Junker RR, Bleil R, Daehler CC, Blüthgen N (2010) Intrafloral resource partitioning between endemic and invasive flower visitors: Consequences for pollinator effectiveness. Ecological Entomology 35:760-767. https://doi.org/10.1111/j.1365-2311.2010.01237.x

Junker RR, Daehler CC, Stefan D, Keller A, Blüthgen N (2011) Hawaiian ant-flower networks: Nectar-thieving ants prefer undefended native over introduced plants with floral defenses. Ecological Monographs 81:295311. https://doi.org/10.1890/10-1367.1

Kato M, Kawakita A (2004) Plant-Pollinator Interactions in New Caledonia Influenced by Introduced Honey Bees. American Journal of Botany 91:1814-1827

Kato M, Shibata A, Yasui T, Nagamasu H (1999) Impact of introduced honeybees, Apis mellifera, upon native bee communities in the Bonin (Ogasawara) Islands. Researches on Population Ecology 41:217-228. https://doi.org/10.1007/s101440050025

Keir, M. (2015) Cyanea grimesiana. The IUCN Red List of Threatened Species 2015: e.T78777135A78777138. http://dx.doi.org/10.2305/IUCN.UK.20154.RLTS.T78777135A78777138.en

Keir M, Kwon J, Caraway VL, Weisenberger L (2015) Cyanea longiflora. The IUCN RedList of Threatened Species 2015: e.T78777282A78777287. http://dx.
doi.org/10.2305/IUCN.UK.2015-4.RLTS.T78777282 A78777287.en

Keir M, Portner T, Caraway VL, Kwon J (2015) Delissea waianaeensis. The IUCN RedList of Threatened Species 2015: e.T79864848A79864881. http://dx.doi.org 10.2305/IUCN.UK.2015-

4.RLTS.T79864848A79864881.en

Kelly D, Ladley JJ, Robertson AW, Anderson SH, Wotton DM, Wiser SK (2010) Mutualisms with the wreckage of an avifauna: The status of bird pollination and fruitdispersal in New Zealand. New Zealand Journal of Ecology 34:66-85

Kiers ET, Palmer TM, Ives AR, et al (2010) Mutualisms in a changing world: an evolutionary perspective. Ecology Letters 1459-1474. https://doi.org/10.1111/j.14610248.2010.01538.x

Koch JB, Sahli HF (2013) Patterns of flower visitation across Elevation and Succssional Gradients in Hawai'i. Pacific Science 67: 253-266

Kolb A, Ehrlén J (2010) Environmental context drives seed predator-mediated selection on a floral display trait. Evolutionary Ecology 24:433-445. https://doi.org/10.1007/s10682-009-9316-2

Krauss SL, Phillips RD, Karron JD, Johnson S, Roberts D, Hopper S (2017) Novel Consequences of Bird Pollination for Plant Mating. Trends in Plant Science 22:395-410.

https://doi.org/10.1016/j.tplants.2017.03.005

Lammers TG (2005) Revision of Delissea (Campanulaceae-Lobelioideae). American Society of Plant Taxonomists 73:1-75

Lammers TG (1991) Systematics of Clermontia (Campanulaceae-Lobelioideae) Systematic Botany Monographs, Vol. 32. American Society of Plant Taxonomists: 1-97

Lammers TG, Weller SG, Sakai Annk (1988) Japanese White-eye, an Introduced Passerine, Visits the Flowers of Clermontia arhorescens, an Endemic Hawaiian Lobelioid. Pacific Science 41:74-78

Lázaro A, Lundgren R, Totland Ø (2009) Co-Flowering Neighbors Influence the Diversity and Identity of Pollinator Groups Visiting Plant Species. Oikos 118:691702

Lord JM (1991) Pollination and seed dispersal in freycinetia baueriana, a dioecious liane that has lost its bat pollinator. New Zealand Journal of Botany 29:83-86. https://doi.org/10.1080/0028825X.1991.10415545

Magnacca KN, King CBA (2013) Assessing the presence and distribution of 23 Hawaiian yellow-faced bee species on lands adjacent to military installations on $\mathrm{O}^{\prime} \mathrm{ahu}$ and Hawai'i Island. Honolulu (HI): Pacific Cooperative Studies Unit, University of Hawaii at Manoa. Technical Report, 185. 26 pp.

Marcus Rowcliffe J, Carbone C, Jansen PA, Kays R, Kranstauber B (2011) Quantifying the sensitivity of 
camera traps: An adapted distance sampling approach. Methods in Ecology and Evolution 2:464-476. https://doi.org/10.1111/j.2041-210X.2011.00094.x

Miller AE, Brosi BJ, Magnacca K, Daily G, Pejchar L (2015) Pollen carried by native and nonnative bees in the large-scale reforestation of pastureland in Hawai' $i$ : Implications for pollination. Pacific Science 69:67-79. https://doi.org/10.2984/69.1.5

Mitchell RJ, Irwin RE, Flanagan RJ, Karron JD (2009) Ecology and evolution of plant-pollinator interactions. Annals of Botany 103:1355-1363. https://doi.org/10.1093/aob/mcp122

Morse NB, Pellissier PA, Cianciola EN, Brereton R, Sullivan M, Nicholas K (2016) Novel ecosystems in the Anthropocene: a revision of the novel ecosystem concept for pragmatic applications. Ecology and Society 19: https://doi.org/10.5751/ES-06192-190212

Mortensen HS, Dupont YL, Olesen JM (2008) A snake in paradise: Disturbance of plant reproduction following extirpation of bird flower-visitors on Guam. Biological Conservation 141:2146-2154. https://doi.org/10.1016/ j.biocon.2008.06.014

Nottebrock H, Schmid B, Mayer K, Devaux C, Esler K, Böhning-Gaese K, Schleuning M, Pagel J, Schurr F (2017) Sugar landscapes and pollinator-mediated interactions in plant communities. Ecography 40:1129 1138. https://doi.org/10.1111/ecog.02441

Ollerton J, Cranmer L, Stelzer RJ, Sullivan S, Chittka L (2009) Bird pollination of Canary Island endemic plants. Naturwissenschaften 96:221-232. https://doi.org/10.1007/s00114-008-0467-8

Pattemore DE, Wilcove DS (2012) Invasive rats and recent colonist birds partially compensate for the loss of endemic New Zealand pollinators. Proceedings of the Royal Society B: Biological Sciences 279:1597-1605. https://doi.org/10.1098/rspb.2011.2036

Pender RJ, Morden CW, Paul RE (2014) Investigating the pollination syndrome of the hawaiian lobeliad genus Clermontia (Campanulaceae) using floral nectar traits. American Journal of Botany 101:201-205. https://doi.org/10.3732/ajb.1300338

Pratt LW, Vandemark JR, Euaparadorn M (2010) Technical Report HCSU-015 Limiting factors of five rare plant species in mesic forests, Hawai $i$ volcanoes national park. 96720:

Pratt TK, Atkinson CT, Banko PC, BL Woodworth, JD Jacobi (2009) Conservation Biology of Hawaiian Forest Birds: Implications for Island Avifauna. Yale University Press

Primack RB, Inouye DW (1993) Factors Affecting Pollinator Visitation Rates - a Biogeographic Comparison. Current Science 65:257-262

Rathcke B (1983) Competition and Facilitation among Plants for Pollination. Academic Press, Inc.
Robertson AW, Ladley JJ, Kelly D (2005) Effectiveness of short-tongued bees as pollinators of apparently ornithophilous New Zealand mistletoes. Austral Ecology 30:298-309. https://doi.org/10.1111/j.1442-9993.2005. 01474.x

Roddy KM, Arita-Tsutsumi L (1997) A History of Honey Bees in the Hawaiian Islands. Hawaiian Pacific Agriculture 8:59-70

Rojas-Nossa SV, Sánchez JM, Navarro L (2016) Nectar robbing: a common phenomenon mainly determined by accessibility constraints, nectar volume and density of energy rewards. Oikos 125:1044-1055. https://doi.org/10.1111/oik.02685

Rosas-Guerrero V, Aguilar R, Martén-Rodríguez S, Ashworth L, Lopezaraiza-Mikel M, Bastida J, Quesada M (2014) A quantitative review of pollination syndromes: Do floral traits predict effective pollinators? Ecology Letters 17:388-400. https://doi.org/10.1111/ele.12224

Roubik DW (1982) The Ecological Impact of Nectar-Robbing Bees and Pollinating Hummingbirds on a Tropical Shrub. Ecology 63:354-360

Santos J dos, Varassin IG, Muschner VC (2018) Effects of neighbourhood on pollination and seed dispersal of a threatened palm. Acta Oecologica 92:95-101. https://doi.org/10.1016/j.actao.2018.08.010

Saracco JF, Collazo JA, Groom MJ, Carlo TA (2005) Crop size and fruit neighbourhood effects on bird visitation to fruiting Schefflera morototoni trees in Puerto Rico. Biotropica 37:81-87. https://doi.org/10.1111/j.17447429.2005.04040.x

Sargent S (1990) Neighbourhood Effects on Fruit Removal by Birds: A Field Experiment with Viburnum Dentatum (Caprifoliaceae). Ecology 71:1289-1298

Shay K, Drake DR, Taylor AD, et al (2016) Alien insects dominate the plant-pollinator network of a Hawaiian coastal ecosystem. Pacific Science 70:409-429

Shay KR, Drake DR (2018) Pollination biology of the Hawaiian coastal vine Jacquemontia sandwicensis (Convolvulaceae). Pacific Science 72: 485-499

Shiels AB, Drake DR (2011) Are introduced rats (Rattus rattus) both seed predators and dispersers in Hawaii? Biological Invasions 13:883-894. https://doi.org/10. 1007/s10530-010-9876-7

Smith AD, McWilliams SR (2014) Fruit removal rate depends on neighbourhood fruit density, frugivore abundance, and spatial context. Oecologia 174:931-942. https://doi.org/10.1007/s00442-013-2834-1

Smith TB, Freed LA, Lepson JK, Carothers JH (1995) Evolutionary Consequences of Extinctions in Populations of a Hawaiian Honeycreeper. Conservation Biology 9:107-113. https://doi.org/10.1046/j.15231739.1995.09010107.x 
Snelling RR (2003) Bees of the Hawaiian Islands, Exclusive of Hylaeus (Nesoprosopis) (Hymenoptera: Apoidea). Source: Journal of the Kansas Entomological Society 76:342-356

Team RC (2020) A Language and Environment for Statistical Computing

Totland O, Nielsen A, Bjerknes A, Ohlson M (2006) Effects of an Exotic Plant and Habitat Disturbance on Pollinator Visitation and Reproduction in a Boreal Forest Herb. American Journal of Botany 93:868-873

Traveset A, Richardson DM (2006) Biological invasions as disruptors of plant reproductive mutualisms. Trends in Ecology and Evolution 21:208-216. https://doi.org/10.1016/j.tree.2006.01.006

Tylianakis JM, Didham RK, Bascompte J, Wardle DA (2008) Global change and species interactions in terrestrial ecosystems. Ecology Letters 11:1351-1363. https://doi.org/10.1111/j.1461-0248.2008.01250.x

Vaughton G (1996) Pollination disruption by European honeybees in the Australian bird-pollinated shrub Grevillea barklyana (Proteaceae). Plant Systematics and Evolution 200:89-100. https://doi.org/10.1007/ $\underline{\text { BF00984750 }}$

Vizentin-Bugoni J, Tarwater CE, Foster JT, Drake D, Gleditsch J, Hruska A, Patrick K, Sperry J (2019) Structure, spatial dynamics, and stability of novel seed dispersal mutualistic networks in Hawai'i. Science 364:78-82. https://doi.org/10.1126/science.aau8751

Wagner WL, Herbst DR, Sohmer SH (1999) Manual of the Flowering Plants of Hawaii. University of Hawaii Press

Walsh SK, Pender RJ, Junker RR, Daehler C, Morden C, Lorence D (2019) Pollination biology reveals challenges to restoring populations of Brighamia insignis (Campanulaceae), a critically endangered plant species from Hawai'i. Flora: Morphology, Distribution,
Functional Ecology of Plants 259:151448. https://doi.org/10.1016/j.flora.2019.151448

Whelan RJ, Beynon F, England PR (2001) A molecular genetic assessment of mating-system variation in a naturally bird-pollinated shrub: Contributions from birds and introduced honeybees. Conservation Biology 15:1645-1655. https://doi.org/10.1046/j.1523-1739.2001. 00236.x

Wilmshurst JM, Hunt TL, Lipo CP, Anderson AJ (2011) High-precision radiocarbon dating shows recent and rapid initial human colonization of East Polynesia. Proceedings of the National Academy of Sciences of the United States of America 108:1815-1820. https://doi.org/10.1073/pnas.1015876108

Wilson EE, Sidhu CS, Levan KE, Holway DA (2010) Pollen foraging behaviour of solitary Hawaiian bees revealed through molecular pollen analysis. Molecular Ecology 19:4823-4829. https://doi.org/10.1111/j.1365294X.2010.04849.x

Wood KR, Oppenheimer H, Keir M (2019). A checklist of endemic Hawaiian vascular plant taxa from the Hawaiian Islands that are considered possibly extinct in the wild. Technical Report. https://www. researchgate.net/publication/332933164

World Conservation Monitoring Centre (1998) Clermontia persicifolia. The IUCN Red List of Threatened Species 1998: e.T33570A9793879. http://dx.doi.org/10.2305/IUCN.UK.1998.RLTS.T33570 A9793879.en

Zhang Y, Wang Y, Guo Y (2007) Effects of nectar-robbing on plant reproduction and evolution. Frontiers of Biology in China 2:443-449. https://doi.org/10.1007/s11515$\underline{007-0068-5}$

Zuur AF, Ieno EN, Elphick CS (2010) A protocol for data exploration to avoid common statistical problems. Methods in Ecology and Evolution 1:3-14. https://doi.org/10.1111/j.2041-210x.2009.00001.x 